\title{
The Indigenous' Participation in Preserving Cultural Heritage of Bena Traditional Village as a Tourist Attraction in Bajawa, Ngada Regency, East Nusa Tenggara
}

\author{
Francisca Titing Koerniawaty \\ International Bali Institute of Tourism, Bali, Indonesia \\ I Wayan Ardika, Made Budiarsa, I Nyoman Darma Putra \\ Udayana University, Bali, Indonesia
}

\begin{abstract}
The commodification of cultural heritage has positive implications to encourage the creativity of cultural artists and aboriginal in creating variants of cultural products as an improvement of prosperity; however, it can also has negative implications, such as a shift or loss of the essence of cultural and religious sounds that is able to lead to conflict, natural destruction, sexual services, and marginalization. The negative implications can be overcome by the participatory of all stakeholders in preserving the sustainability of cultural heritage as touristic. This study focused on three issues. Firstly, the patterns of aboriginals' participatory in preserving cultural heritage as a touritic. Secondly, the level of aboriginals' response to tourists. Thirdly, the aboriginals' complaint in preserving cultural heritage as a touristic. In accordance with these problems, the operational definition of study is the concept of cultural heritage tourism, tourist attraction, aboriginal, and traditional village of Bena. The theoretical review used to analyze the problem is community participatory theory in tourism development by Tosun and Irridex theory of attitude change of aboriginal by Doxey. This qualitative descriptive study is located in traditional village of Bena, Bajawa, Ngada Regency, East Nusa Tenggara with the selection of informants who understand the problem. The results of the study indicate that the aboriginals' participatory is spontaneous. The level of aboriginals' response is apathy level. The several complaints in preserving cultural heritage involving a great expense of traditional house maintenance, the processing time of traditional woven and the emergence of modern ja'i dance and music.
\end{abstract}

Keywords: cultural heritage tourism, tourist attraction, aborignal, traditional village of Bena

\section{Introduction}

The commodification of cultural heritage has positive implications to encourage the creativity of cultural artists and aboriginals in creating variants of cultural products as an improvement of prosperity (Said, 1993; Ardika, 2007); however, it can also has negative implications, such as a shift or loss of the essence of cultural and

Francisca Titing Koerniawaty, M.Pd., Hospitality Departement, International Bali Institute of Tourism, Bali, Indonesia.

I Wayan Ardika, M.A., Dr., professor, Udayana University, Bali, Indonesia.

Made Budiarsa, M.A., Dr., professor, Udayana University, Bali, Indonesia.

I Nyoman Darma Putra, M., Litt., Dr., professor, Udayana University, Indonesia.

Correspondence concerning this article should be addressed to Francisca Titing Koerniawaty, International Bali Institute of Tourism, Jl. Tari Kecak no. 12, Gatot Subroto Timur, Denpasar, Bali 80239, Indonesia. Email: koe.titing@gmail.com. 
religious meaning that is able to lead to conflict, natural destruction, sexual services, and marginalization (Tung \& Ritchie, 2011; Pearce, 2009; Cohen, 1988; Picard, 2006; Urry, 1990; Burns and Holden, 1995). The exessive consumtion to cultural heritage is also able to reduce the aesthetics of product and tradition due to cultural erosion. The loss of culture essence is able to cause that culture will seem hybrid, homogeneous, even extraordinary, and not monolithic. There should not be excessive anxiety about the negative implications of commodification on cultural heritage since arts, crafts, and various aspects of local culture could be revitalized through tourism (Said, 1993; Ardika, 2007). The phenomenon of commodification of cultural heritage occurs in several countries that utilize local culture as touristic. In Bali, barong dance is a sacred dance that has been monetized; however, it does not lead to conflict since the community understands the difference between sacred and profane barong (Pitana, 2006). In contrast to the alarde ritual in the Basque city of Spain that had lost its meaning since it was forced to produce economic improvements for people involved in these activities, such as dancers and musicians (Cohen, 1988). Economic benefits as a positive implication of tourism activities were also experience by community in Hong Kong through the bun festival while the meaning of cultural authenticity has lost for economic purposes by replacing the authentic material with the plastic one (Chew, 2009). For Cohen (1988) and Grunewald (2002), the loss of the meaning of cultural products could actually add to the old culture become a new culture that can be considered authentic as a part of patina process. Based on some of these phenomena, this study focused on three issues. Firstly, the patterns of aboriginals' participatory in preserving cultural heritage as a touristic. Secondly, the level of aboriginals' response to tourists. Thirdly, the aboriginals' complaint in preserving cultural heritage as touristic. The study is also aimed to encourage the interest research on cultural tourism in East Nusa Tenggara, and practically provide recommendations for the aboriginal to be closer to their culture for raising awareness to participate in preserving the cultural heritage of Bena Village sustainability as touristic. The results of the study could recommend in decision making to follow up the negative implications of excessive consumption of cultural heritage commodification.

\section{Literature Review}

The previous studies as references are the research entitled "Beyond Authenticity and Commodification" by Cole (2007), and Moswete, Saarinen, and Monare's research (2015) entitled "Perspectives on Cultural Tourism: A Case Study of Bahurutshe Cultural Village for Tourism in Botswana". The concept as a limitation of technical terminology is cultural heritage tourism (S. S. Mousavi, Doratli, S. N. Mousavi, \& Moradiahari, 2016, p. 71; Ministry of National Education, 2008), tourist attraction (Ardika, 2012, p. 26), aboriginal (United Nations Development Program 2004; Nakashima et al., 2000), and traditional village of Bena (Moi, 2010). The theoretical basis to analyze the research problem is the theory of community participation in tourism development (Tosun, 2006) and the irritation theory of attitudes shift of aboriginal in interacting with tourists (Doxey, 1975).

\section{Research Method}

This is a qualitative descriptive study with a phenomenological approach located in the traditional village of Bena, Tiworiwu Village, Jerebu'u District, Bajawa, Ngada Regency, Central Flores, East Nusa Tenggara Province. Data were collected through passive participatory observation techniques, in-depth interviews, FGDs, and documentation studies by determining informants who understand problems, such as curator of cultural heritage, the head of local customs, women as heirs of traditional houses, the leader of tourist destination 
management, village heads, the head, and assistant of local tourism of Ngada Regency.

\section{Discussion}

In accordance with the theory of Tosun (2006), it can be recognized that the aboriginal participatory in preserving traditional houses is active and without any pressure to maintain the homogenous of design and architecture. The development is directly carried out by aboriginal without any pressure as a result of manipulation that is supported by the government actively in its renovation and maintenance. It is self-planning participatory since the aboriginal is directly responsible in deciding to construct, renovate, and maintain the architecture of traditional houses sustainability. The others participatory in preserving the cultural heritage is respecting the traditional ceremonial reba as an annual customs celebration and ka'sao is the traditional ceremony after constructing or renovating traditional houses. Besides the traditional architecture and ceremonial respect as a participatory, the aboriginal also participates to preserve the sustainability and development traditional crafts, such as local motif woven, traditional bags, and attributes of ceremonial made of local palm leaves or plastic. The government has a central role to support the aboriginals' participatory by motivating and training local leaders to take on leadership roles (UN, 1981). In accordance with the statement justification of De Kadt (1979a; 1979b), Aramberri (2001), Pearce (1998; 2005), and Doxey (1975), it could be stated that the aboriginals' response to tourists is at the level of apathy, which is a reciprocal relationship as a result of the development of tourism in the village of Bena. The level of apathy was emerged as a part of services that is provided by the aboriginal to improve the quality of life. The aboriginal has several complaints in preserving cultural heritage, such as high expense of traditional house maintenance; the production process of traditional woven is not comparable with economic contribution and less time for community gathering due to formal field.

\section{Conclusion}

The aboriginals' participatory in preserving the cultural heritage of Traditional Village of Bena is spontaneous in order to be maintained. The aboriginals' response to tourists is at the position of apathy. It could be minimized through several trainings and FGDs by participating all stakeholders to develop the sustainability of the Traditional Village of Bena as a tourist destination. If there are indications of disrespect towards tourists, it needs participatory from all stakeholders to anticipate as not to lead to the level of antagonism, then it would lead to the decline stages of tourist destinations. The complaints to cultural heritage preservation involving high expense of traditional house maintenance; the production process of traditional woven is not comparable with economic contribution and less time for community gathering due to formal field. It could be overcome through increasing the distribution of benefits of destination management for the aboriginal to encourage more active and spontaneous participatory.

\section{References}

Adorno, T. W. (1979). The dialectic of enlightenment. London: Verso.

Ali-Knight, J. M. (2011). The role of niche tourism products in destination development. UK: Edinburgh Napier University. Aramberri, J. (2001). The host should get lost. Paradigms in the tourism theory. Annals of Tourism Research, 28(3), 738-761.

Ardika, I. W. (2003). Pariwisata Budaya Berkelanjutan. Refleksi dan Harapan Di Tengah Perkembangan Global. Denpasar: Program Studi Magister (S2) Kajian Pariwisata Universitas Udayana. Ardika, I. W. (2007). Pusaka Budaya dan Pariwisata. Denpasar: Pustaka Larasan.

Ardika, I. W. (2012). Pariwisata Minat Khusus Berbasis Arkeologi. Dalam Arkeologi untuk Publik. Jakarta: Ikatan Ahli 
Arkeologi Indonesia.

Ardika, I. W. (2015). Warisan Budaya Perspektif Masa Kini. Denpasar: Program Studi Magister (S2) Kajian Pariwisata Universitas Udayana.

Barker, C. (2004). The SAGE dictionary of cultural studies. London: SAGE Publications Ltd.

Burns, P., \& Holden, A. (1995). Tourism: A new perspective. New Jersey: Prentice Hall.

Chew, M. M. (2009). Cultural sustainability and heritage tourism: Problems in developing bun festival tourism in Hong Kong.

Journal of Sustainable Development November, 2(2), 32-42.

Cohen, E. (1980). Rethinking the sociology of tourism. Annals of Tourism Research, 6, 18-35.

Cohen, E. (1988). Authenticity and commoditization in tourism. Annals of Tourism Research, 15, 371-386.

Cole, S. (2007). Beyond authenticity and commodification. Annals of Tourism Research, 34, 943-960.

Cole, S. (2008). Living in hope: Tourism and poverty alleviation in flores. In P. Burns and M. Novelli (Eds.), Tourism Development: Growth, Myths and Inequalities. Oxford: CABI.

De Kadt, E. (1979 a). Social Planning for Tourism in the Development Countries. Annals of Tourism Research, 6(1), 36-48.

De Kadt, E. (1979b). Tourism-Passport to development? New York: Oxford University Press.

Dixey, L. M. (2007). Competing with the best: Good practices in community-based tourism in the Caribbean. St. Michael, Barbados: Caribbean Tourism Organization.

Doxey, G. (1975). A causation theory of visitor-resident irritants: Methodology and research inferences in the impact of tourism. In The Sixth Annual Conference Proceedings (pp.195-198). San Diego: The Travel Research Association

Grunewald, R. (2002). Tourism and cultural revival. Annals of Tourism Research, 29, 1004-1021.

Ministry of National Education. (2008). Retrieved from https://kebudayaan.kemdikbud.go.id/wpcontent/uploads/2016/05/

Moi, P. M. D. (2010). Kajian Tradisi Megalitik di Kampung Bena. Ngada: Departemen Pendidikan dan Kebudayaan Pemuda dan Olahraga.

Moswete, N., Saarinen, J., \& Monare, J. M. (2015). Perspectives on cultural tourism: A Case study of bahurutshe cultural village for tourism in Botswana Nordic Journal of African Studies, 24(3\&4), 279-300.

Mousavi, S. S., Doratli, N., Mousavi, S. N., \& Moradiahari, F. (2016). Defining cultural tourism. International Conference on Civil, Architecture and Sustainable Development (CASD-2016), December 1-2, London, UK.

Nakashima, D., Prott, L. \& Bridgewater, P. (2000).Tapping into the world's wisdom, UNESCO Sources, 125, July-August, p. 12.

Pearce, P. L., \& Moscardo, G. M. (1998). Role of interpretation in influencing visitor satisfest case study. In: Faulkner, W., Tideswell, C. and Weaver, D. (eds) Progress in Tourism and Hospitality search, Proceeding of the eighth australian tourism and hospitality research conference. Bureau tourism Research, canberra, pp. 259-308.

Pearce, P. L., \& Moscardo, G. M. (2005). The relationships between travelers career levels and concept of authenticity. Australian Journal of Psychology, 37, 157-174.

Pearce, P. L. (2009). The relationship between positive psychology and tourist behavior studies. Tourism Analysis, 14(1), 37-48.

Picard, M. (2006). Bali: Pariwisata Budaya dan Budaya Pariwisata. Jakarta: Kepustakaan Populer Gramedia.

Pitana, I. G. (2006). Bali Bangkit Kembali: Industri Budaya Dalam Pariwisata Bali: Reproduksi, Presentasi, Konsumsi, dan Konservasi Kebudayaan. Kerjasama Departemen Kebudayaan dan Pariwisata Republik Indonesia dan Universitas Udayana.

Said, E. (1993). Culture and imperialism. London: Chatto \& Windus.

Sugiyono, P. (2013). Metode Penelitian Kuantitatif dan Kualitatif dan R \& D. Bandung: Alfabeta.

Tosun, C. (1999). Towards a typology of community participation in the tourism development process. Anatolia: An International Journal of Tourism and Hospitality Research, 10(2), 113-134. Retrieved from http://dx.org/10.1080/130332917.1999.9686975

Tosun, C. (2002). Limits to community participation in the tourism development process in developing countries. Tourism Management, 21(6), 613-633.

Tosun, C. (2005). Stages in the emergence of a participatory tourism development approach in the developing world. Elsevier Geoforum, 36, 333-352. Retrieved from http://www.elsevier.com/locate/geoforum

Tosun, C. (2006). Tourism management: Expected nature of community participation in tourism development. Retrieved March 23 , 2018, from http:// www.scribd.com/document/244034360/Tosun-Cevat-Expected

Tung, V. W. S., \& Ritchie, J. R. B. (2011). Investigating the memorable experiences of the senior travel: An examination of the reminiscence bump. Journal of Travel \& Tourism Marketing, 28(3), 331-343. 
United Nations. (1981). Popular Participation as a Strategy@ Promoting Community-lave1 Action and National Development. Department of International Economic and Social affairs. New York United Nations.

United Nations Development Program. (2004). Democracy in Latin America: Towards a Citizens' Democracy. 987-0085-X. Retrieved from http://democracia. undp. org/Informe/Default. asp?Menu=15\&Idioma=2

United Nations Development Program. (2004). Human Development Report 2004 Cultural Liberty in Today's Diverse World. Urry, J. (1990). The tourist gaze. London: Sage.

Wang, Y. (2006). Residents' attitudes toward tourism development: A case study of Washington. Retrieved March 12, 2018, from http://www.nrs.fs.fed.us/pubs/gtr/gtr_nrs-p-14/54-wang-p-14.pdf 